\title{
VAD Regimen
}

National Cancer Institute

\section{Source}

National Cancer Institute. VAD Regimen. NCI Thesaurus. Code C63498.

A regimen consisting of vincristine, doxorubicin and dexamethasone used as induction treatment for plasma cell myeloma. 